\title{
Characterization of a rhabdovirus isolated from carpione Salmo trutta carpio in Italy
}

\author{
G. Bovo ${ }^{1}$, N. J. Olesen ${ }^{2}$, P. E. V. Jørgensen ${ }^{2}$, W. Ahne ${ }^{3}$, J. R. Winton ${ }^{4}$ \\ ${ }^{1}$ Istituto Zooprofilattico Sperimentale delle Venezie, Via G. Orus 2, I-35129 Padova, Italy \\ ${ }^{2}$ National Veterinary Laboratory, Hangovej 2, DK-8200 Aarhus N, Denmark \\ ${ }^{3}$ Institute of Zoology, Fishery Biology and Fish Diseases, Kaulbachstrasse 37, D-80539 Munich, Germany \\ ${ }^{4}$ National Fisheries Research Center, Bldg 204 Naval Station, Seattle, Washington 98115, USA
}

\begin{abstract}
A virus, strain 583, was isolated from carpione Salmo trutta carpio fry exhibiting high mortality. The virus was not neutralized by rabbit antisera against the fish rhabdoviruses viral haemorrhagic septicaemia virus (VHSV), infectious hematopoietic necrosis virus, eel rhabdovirus European X, spring viraemia of carp virus or pike fry rhabdovirus, or against the birnavirus infectious pancreatic necrosis virus. The virus replicated in several fish cell lines incubated at 20 to $25^{\circ} \mathrm{C}$ and grew optimally in the bluegill fry (BF-2) and fathead minnow (FHM) cell lines. Electron microscopy of infected BF-2 cell cultures revealed the presence of typical rhabdovirus particles, and immunofluorescent staining was observed using various polyclonal and monoclonal antibodies (MAbs) against Egtved virus, the causative agent of viral haemorrhagic septicaemia. The staining by a MAb against the nucleoprotein (N) of VHSV was particularly strong, a MAb against the glycoprotein (G) gave a moderate reaction, whereas a second MAb against the $G$ protein and MAbs against the matrix proteins, $M_{1}$ and $\mathrm{M}_{2}$, of VHSV did not react. Fluorescence titres using 3 rabbit antisera against whole Egtved virus varied between negative and moderately positive. Western blotting using polyclonal and monoclonal sera confirmed that both the $\mathrm{N}$ and $\mathrm{G}$ proteins of the carpione virus shared some epitopes with those of VHSV, but the $M_{1}$ and $M_{2}$ proteins did not. SDS-PAGE showed the structural proteins of the carpione virus produced a pattern typical of members of the Lyssavirus genus of the Rhabdoviridae and the molecular weights were very similar to those of VHSV, except for the $M_{2}$ protein which was somewhat smaller. Infection trials showed the carpione virus induced high mortalities in carpione fry but not in rainbow trout Oncorhynchus mykiss fry. The carpione virus was clearly distinguishable from Egtved virus despite limited serological cross reaction. Since it was also easily distinguishable by immunofluorescence from the other fish rhabdoviruses included in the present study as well as in studies published elsewhere, it is concluded that the virus is a previously undescribed one. It is proposed that the virus be given the preliminary designation 'carpione rhabdovirus'
\end{abstract}

KEY WORDS: Rhabdovirus · Carpione Salmo trutta carpio - Fish virus

\section{INTRODUCTION}

According to Melotto \& Oppi (1987), carpione Salmo trutta carpio is a salmonid species with an uncertain taxonomic classification. Apparently, carpione are present only in Garda Lake, Italy, where they have become highly adapted, spawning twice a year in reproduction areas at depths of 70 to $300 \mathrm{~m}$. The species is mainly planktophagous. In spring 1988 , attempts were initiated by the Ente Sviluppo Agricolo del Veneto (ESAV) to propagate carpione artificially with the aim of increasing the population, which in recent years has suffered a significant reduction (Melotto \& Oppi 1987). Fertilized eggs, obtained from captured wild spawners, were transferred to the ESAV experimental lake station in Bardolino, Italy, and hatched at 10 to $12^{\circ} \mathrm{C}$. Fry were fed with phytoplankton. After $2 \mathrm{wk}$, the fry were transferred to a trout farm supplied with river water. At the end of June, 3 mo after hatching, high mortality occurred in the fry. This paper describes the isolation of a novel virus from the diseased fish. 


\section{MATERIALS AND METHODS}

Virological examination. Diseased, 3 mo old carpione fry were homogenized and examined by cell culture inoculation according to standard diagnostic procedures using the rainbow trout gonad (RTG-2) (Wolf \& Quimby 1962) and the epithelioma papulosum cyprini (EPC) (Fijan et al. 1983) cell lines incubated at $15^{\circ} \mathrm{C}$. Virus identification was attempted by neutralization tests using rabbit antisera to: viral haemorrhagic septicaemia virus (VHSV), infectious hematopoietic necrosis virus (IHNV), eel rhabdovirus European $X$ (EVEX), spring viraemia of carp virus (SVCV), pike fry rhabdovirus (PFR) and infectious pancreatic necrosis virus (IPNV).

Bacteriological examination. Kidney material was testec for bacteria by inoculation of blood agar and TSA agar plates which were incubated at room temperature for $5 \mathrm{~d}$.

Cell cultivation. All the cell lines used were cultivated using Eagle's minimum essential medium to which had been added $10 \%$ (or occasionally $2 \%$ ) foetal bovine serum and antibiotics and Tris buffer in standard concentration, using commercially available plastic flasks and trays. Incubation temperatures, unless otherwise stated, were $20^{\circ} \mathrm{C}$ during cell outgrowth and $15^{\circ} \mathrm{C}$ after inoculation of virus.

Virus isolates. IHNV strain 32/87, isolated in France, was obtained from Dr P. de Kinkelin, INRA, Paris, France. The VHSV isolates used were reference strain F1 (Jensen 1965) and strains DK-3592-B and Saone, isolated by the authors in Denmark and Italy, respectively.

Production of antiserum in rabbits. Antiserum to the virus isolate from carpione fry was produced by immunizing rabbits with sucrose-gradient-purified virus according to a previously described purification and immunization schedule (Olesen et al. 1991).

Immunofluorescence (IF). Coverglass $(9 \times 22 \mathrm{~mm})$ cultures of EPC cells were infected by immersion in $1: 50$ or 1:500 dilutions of growth medium from cell cultures showing complete cytopathic effect (CPE). The cultures were incubated at $15^{\circ} \mathrm{C}$ for $24 \mathrm{~h}$. Coverslips were rinsed twice in cell culture medium without serum, fixed in acetone for $15 \mathrm{~min}$, air dried, and stared at $-20^{\circ} \mathrm{C}$ until used. Polyclonal rabbit antisera to VHSV (K05, K59 and 'Pool b'), IHNV (K2702), EVEX (K13), PFR (K45), SVCV (K42) and to carpione isolate 583 as well as monoclonal antibodies (MAbs) to the G (IP1D11 and IP1H3), $N$ (IP5B11), $M_{1}$ (IP1C6), and $M_{2}$ (IP1C3) proteins of VHSV (Lorenzen et al. 1988) were applied as the first antibody layer and the coverglasses were incubated in a humid chamber, either for $30 \mathrm{~min}$ at $37^{\circ} \mathrm{C}$ (rabbit sera) or overnight at $4^{\circ} \mathrm{C}$ (MAbs). Following 3 rinsing cycles as described by Lorenzen et al.
(1988), staining was performed for $30 \mathrm{~min}$ at $37^{\circ} \mathrm{C}$ using fluorescein isothyocyanate (FITC) conjugated swine anti-rabbit Ig or rabbit anti-mouse Ig, respectively, (Dakopatts, Copenhagen) at a dilution of 1.100. Rinsing was then repeated before mounting in glycerol-PBS (phosphate-buffered saline) mixture (pH 8.0). Examination was carried out using an epifluorescence microscope (Olympus Vanox) supplied with a $200 \mathrm{~W}$ mercury lamp and fluorescence oil objectives $(40 \times$ and $100 \times)$.

During experimental infection trials with the carpione virus, tissue from fry that showed signs of disease (e.g. muscle haemorrhages) were processed for IF. Specimens were frozen on metal dishes inside a cryostat chamber at $-20^{\circ} \mathrm{C}$. After $30 \mathrm{~min}, 5$ to $10 \mu \mathrm{m}$ sagittal sections were cut. After air drying, sections were fixed in acetone at $-20^{\circ} \mathrm{C}$ for $10 \mathrm{~min}$. Immunofluorescent staining was conducted using the indirect technique, where rabbit antisera to IHNV, VHSV or the carpione virus were applied as the first antibody and incubated in a humid chamber at $37^{\circ} \mathrm{C}$ for $30 \mathrm{~min}$. Following 3 rinsing cycles, staining was performed at $37^{\circ} \mathrm{C}$ for 30 min using FITC conjugated goat antibody against rabbit Ig (Pasteur Institute, Paris, France) at a dilution of $1: 100$. Rinsing was repeated before mounting in glycerol-PBS mixture buffered at $\mathrm{pH} 9$ with carbonate-bicarbonate solution. Observation was carried out at $400 \times$ using an epifluorescence microscope (Zeiss, Axioskop) supplied with an HBO $100 \mathrm{~W}$ mercury lamp

Electron microscopy. BF-2 cells infected with the carpione virus at a multiplicity of infection (MOI) of 0.1 were incubated at $20^{\circ} \mathrm{C}$ for $48 \mathrm{~h}$. Afterwards, cells were fixed in $2.5 \%$ glutaraldehyde in $0.067 \mathrm{M}$ Sorensen's phosphate buffer $(\mathrm{pH} 7.4)$ for $24 \mathrm{~h}$, washed 3 times with $0.2 \mathrm{M}$ saccharose-Sorensenphosphate buffer and post-fixed with $1 \%$ osmium tetroxide in $0.1 \mathrm{M}$ cacodylate buffer for $2 \mathrm{~h}$. After dehydration in a graded acetone series, the specimens were embedded in Epon 812. Semi-thin sections were stained with $1 \%$ toluidine blue in $1 \%$ borax. Ultrathin sections stained with uranyl acetate and lead citrate were examined using a transmission electron microscope (Zeiss EM 109).

Sodium dodecyl sulfate polyacrylamide gel electrophoresis (SDS-PAGE). SDS-PAGE was performed according to the method of Laemmli (1970) in $1 \mathrm{~mm}$ thick slab gels in a vertical slab gel system. The stacking gel contained $3.5 \%$ acrylamide and $0.11 \%$ bisacrylamide, the separating gel $10 \%$ and $0.31 \%$. The gels were loaded with gradient-purified carpione virus, IHNV (strain 32/87) and VHSV (strain F1). After electrophoresis, the gels were stained by the silver staining method described by Morrissey (1981) or were used for immunoblotting 
Immunoblotting. The protein bands were transferred from polyacrylamide gels to polyvinylidene difluoride membranes (Immobilon, Millipore) according to procedures described by Kyhse-Andersen (1984). Free binding sites were blocked by incubation in PBS with $5 \%$ BSA (bovine serum albumin) for 1 h at $37^{\circ} \mathrm{C}$. After washing in PBS with $0.05 \%$ Tween-20 (PBS-T), the membranes were cut into $30 \mathrm{~mm}$ wide strips, each containing the polypeptides of the 3 viruses. The strips were then incubated overnight with 1:5000 dilutions of protein-A purified rabbit Ig to IHNV or VHSV previously absorbed on EPC and BF-2 cells, or with a pool of the MAbs IP1D11, IP1H3, IP5B11, IP1C6, and IP1C3 against the VHSV polypeptides $G$ ( $2 \mathrm{MAbs}$ ), N, $\mathrm{M}_{1}$ and $\mathrm{M}_{2}$, respectively (Lorenzen et al. 1988). Following three $5 \mathrm{~min}$ rinses in PBS-T, horseradish-peroxidase-conjugated swine antibodies to rabbit Ig or rabbit antibodies to mouse Ig (Dakopatts) were added at a dilution of $1: 1000$. Visualization of bound conjugate and total protein was performed as described by Lorenzen et al. (1988).

Virus replication in different cell lines. Replication of the carpione virus in different cell lines was examined by inoculation of a stock culture (6th passage on EPC cells) into $24 \mathrm{~h}$ old cultures of the following cell lines: RTG-2, EPC, BF-2 (Wolf \& Quimby 1966), fathead minnow (FHM) (Gravell \& Malsberger 1965), chinook salmon embryo (CHSE-214) (Lannan et al. 1984), pike gonad (PG) (Ahne 1979), ovary fluid cells (OFC) (G. Bovo unpubl.j and sea bass line (SBL) (Castric 1984). The cells were grown in $75 \mathrm{~cm}^{2}$ flasks to about $90 \%$ confluence. Cells were inoculated with virus at an MOI ranging from 0.6 to 1.2 . After virus adsorption for $1 \mathrm{~h}$ at $15^{\circ} \mathrm{C}$, the inoculum was removed and the cell sheet washed twice with $5 \mathrm{ml}$ of medium. Afterwards, $20 \mathrm{ml}$ of new medium containing $2 \%$ serum was added to each flask, which was incubated at 20 or $25^{\circ} \mathrm{C}$ as shown in Table 1.

After $7 \mathrm{~d}$, the virus titre in each flask was determined by plaque assay using 24 -well plates of EPC cells. Serial 10 -fold dilutions were prepared and triplicate inocula $\left(0.1 \mathrm{ml}\right.$ well $\left.^{-1}\right)$ of each dilution were plated and allowed to adsorb for $60 \mathrm{~min}$ at $15^{\circ} \mathrm{C}$. Afterwards, the inoculum was removed, $1 \mathrm{ml}$ medium with $0.8 \%$ methylcellulose was added to each well, and plates were incubated at $15^{\circ} \mathrm{C}$ for $7 \mathrm{~d}$. The titres were expressed as the average number of plaque forming units per $\mathrm{ml}\left(\mathrm{PFU} \mathrm{ml} \mathrm{m}^{-1}\right.$ ).

Virus replication at different temperatures. Virus replication in EPC cells incubated at selected temperatures was examined using $75 \mathrm{~cm}^{2}$ flasks infected at an MOI of 0.1 . Virus was inoculated onto drained cell monolayers for $60 \mathrm{~min}$ at $15^{\circ} \mathrm{C}$ followed by 2 washes with $5 \mathrm{ml}$ cell culture medium. The cultures were incubated at $15,20,25$ and $30^{\circ} \mathrm{C}$ for $7 \mathrm{~d}$ and the virus concentrations were determined by plaque titration on EPC cells as described.
Virus stability at selected temperatures. Aliquots of carpione virus in cell culture medium were exposed for $15 \mathrm{~min}$ to each of the following temperatures: $4,30,37$, 42 and $56^{\circ} \mathrm{C}$. Subsequently the residual infectivity was titrated on EPC cells and expressed as PFU ml-1

In vivo passage of carpione virus in rainbow trout fry. Twenty-five rainbow trout Oncorhynchus mykiss fry $(1.0 \mathrm{~g})$ were given an intraperitoneal injection of carpione virus (cell culture passage 8 ). The virus was reisolated from a pool of 2 fish which developed signs of disease such as exophthaimia, petechial haemorrhages in muscles and gills, presence of ascitic fluid in the coelom, cerebral disturbances and severe kidney haemorrhages approximately $5 \mathrm{~d}$ post-infection. The first cell culture passage of this reisolated virus was used in bath infection experiments with rainbow trout fry $(1.25 \mathrm{~g})$.

Experimental infection. Virus titres in the experimental infections were determined by tissue culture infective doses per $\mathrm{ml}\left(\mathrm{TCID}_{50} \mathrm{ml}^{-1}\right.$ ) as described by Reed \& Muench (1938). During infection experiments, experimental fish were kept in $8 \mathrm{l}$ aquaria supplied with tap water at 10 or $15^{\circ} \mathrm{C}$ (see Table 3). The trout fry were fed commercially available trout dry food whereas the carpione fry were not fed because phytoplankton was not available.

Groups of 50 carpione fry $(0.1 \mathrm{~g})$ were exposed by bath infection to $2 \times 10^{6} \mathrm{TCID}_{50} \mathrm{ml}^{-1}$ of the carpione virus, 8 th cell culture passage, or to $4 \times 10^{3} \mathrm{TClD}_{50} \mathrm{ml}^{-1}$ of VHSV (strain Saone), 2nd cell culture passage. Groups of 50 rainbow trout fry $(2 \mathrm{~g})$ were exposed to carpione virus and Saone isolates of VHSV at a titre of $1 \times 10^{5} \mathrm{TCID}_{50} \mathrm{ml}$. In an additional experiment, replicate groups of 50 rainbow trout fry $(1.25 \mathrm{~g})$ were exposed to bath infection with $1 \times 10^{5} \mathrm{TCID}_{50} \mathrm{ml}^{-1}$ of carpione virus ( 1 cell culture passage after 8 in vitro subcultivations and 1 in vivo passage in trout fry) or with VHSV, strain 3592B, cell culture passage 3 (see Table 3) In both experiments, control fish were exposed to water containing cell culture medium without virus. Moribund fry were examined visually for the presence of disease signs and selected samples were processed for virus isolation and/or indirect IF tests.

\section{RESULTS}

\section{Isolation of virus}

Cytopathic effect appeared 48 to $72 \mathrm{~h}$ after inoculation of tissue suspensions from diseased carpione fry into RTG-2 and EPC cell cultures. Bacteriological examination of the affected fry was negative. The virus was not neutralized by rabbit antisera to VHSV, IHNV, EVEX, SVCV, PFR, or IPNV 


\section{Immunofluorescence}

By IF, a positive reaction was observed with 2 of 3 reference quality rabbit antisera made against reference-strain F1 of VHSV One of the sera (Pool b) gave a weak response, the other (K59) a moderate one compared to the reactions obtained with homologous virus.

These 3 rabbit antisera have routinely given strong reactions with a large number of field isolates of VHSV representing all known serotypes (data not shown).

MAb IP5B11, directed against the N protein of VHSV, and MAb IP1D11, directed against the $G$ protein of VHSV, gave a very strong and a moderate reaction (Fig. 1), respectively. No reactions were observed with MAbs recognizing the $M_{1}$ or $M_{2}$ proteins of VHSV nor with MAb IP1H3, which is directed against a $G$ protein epitope different from that reacting with IP1D11 (not shown). Rabbit antisera to IHNV, SVCV, PFR, EVEX and IPNV all gave negative results. The antiserum to the carpione virus induced a brilliant cytoplasmic staining of carpione virus in infected cell cultures and in cryostat sections of infected fish. In contrast the antiserum did not stain cultures infected with VHSV or IHNV.

\section{Electron microscopy}

Thin sections of infected BF-2 cells revealed bulletshaped virus particles (Fig. 2). Based on measurements of 10 particles the mean length of the virion was $175 \pm 16.4 \mathrm{~nm}$ and the mean diameter was $52 \pm 3 \mathrm{~nm}$. Budding nucleocapsids were observed and virions were present in cytoplasmic vesicles. Areas of the cytoplasm associated with budding contained numerous ribosomes

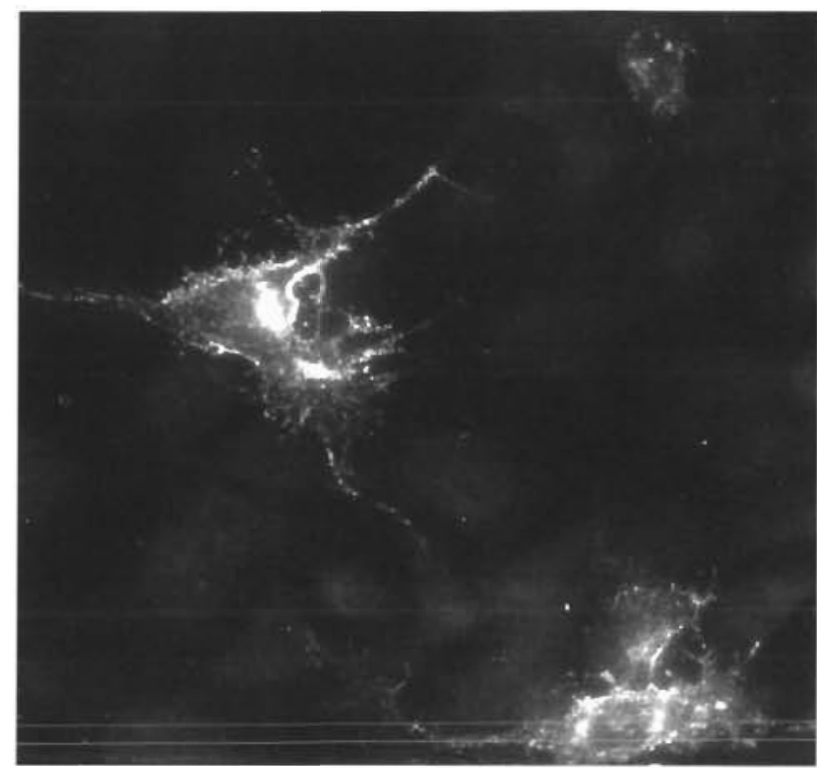

Fig. 1. Immunofluorescence micrograph showing the staining of a carpione-rhabdovirus-infected EPC cell culture with monoclonal antibodies to VHSV-G protein as the primary antibody and FITC-labelled rabbit antibody to mouse Ig as the secondary antibody. $\times 370$

\section{SDS-PAGE}

Gradient-purified carpione virus gave rise to 5 major bands in silver-stained gels (Fig 3). Based on the nomenclature of rhabdovirus polypeptides proposed by Wagner et al. (1972) these bands are called L, G, N, $M_{1}$ and $M_{2}$. The relative mobilities of the respective 5 polypeptides suggested that they had molecular weights of about 190,70,41,28 and $23 \mathrm{kDa}$ (data not

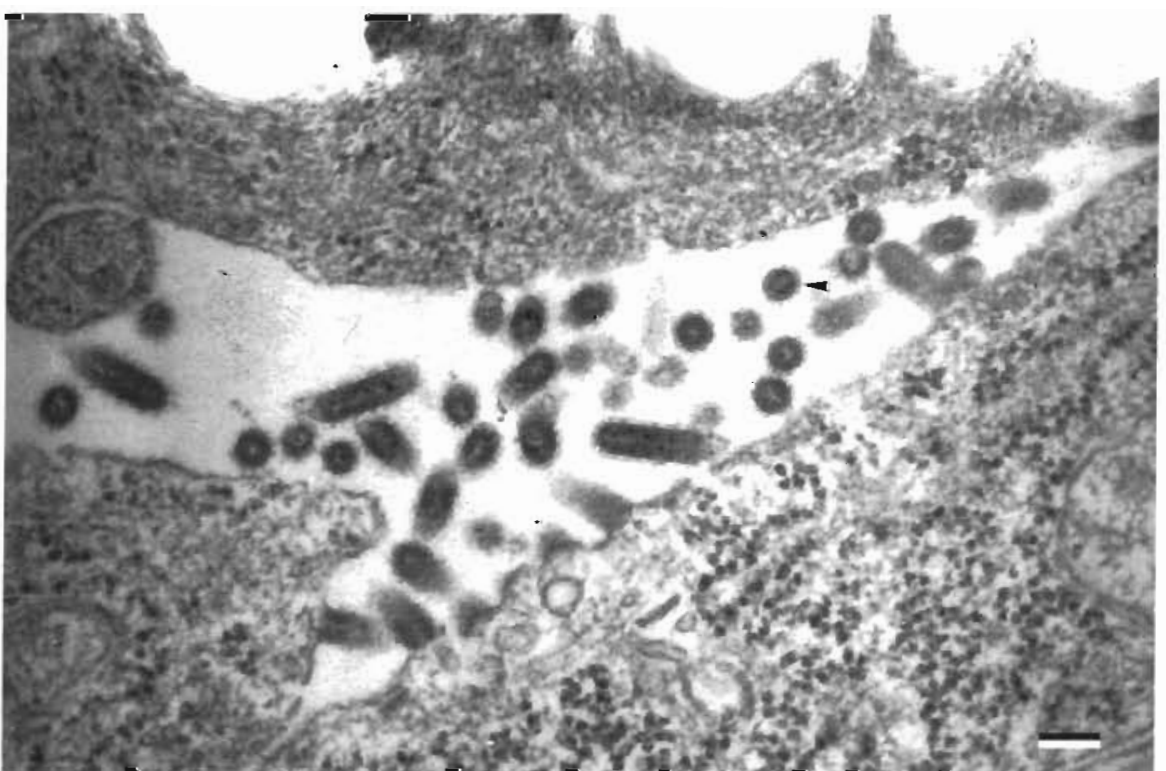

Fig. 2. Electron micrograph showing a thin section of a BF-2 cell infected with the carpione virus. Bullet-shaped particles within a cytoplasmic vesicle and budding nucleocapsids are seen. In the vesicle, cross sections of particles are visible (arrowhead). Vinons measure about $175 \times 52 \mathrm{~nm}$. Note the presence of ribosomes in the vicinity of the budding site. Scale bar $=100 \mathrm{~nm}$ 


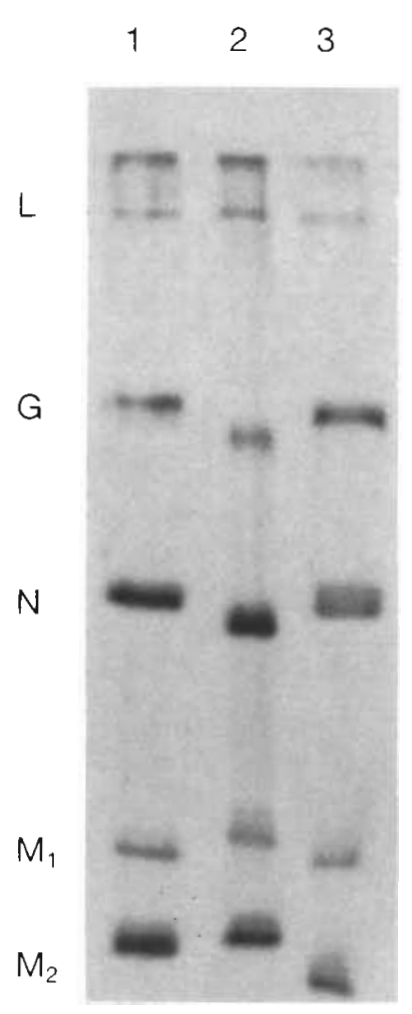

Fig. 3. SDS-PAGE gel stained with silver to reveal the 5 structural proteins $\left(L, G, N, M_{1}\right.$ and $\mathrm{M}_{2}$ ) of: (1) VHSV, (2) IHNV, and (3) carpione virus
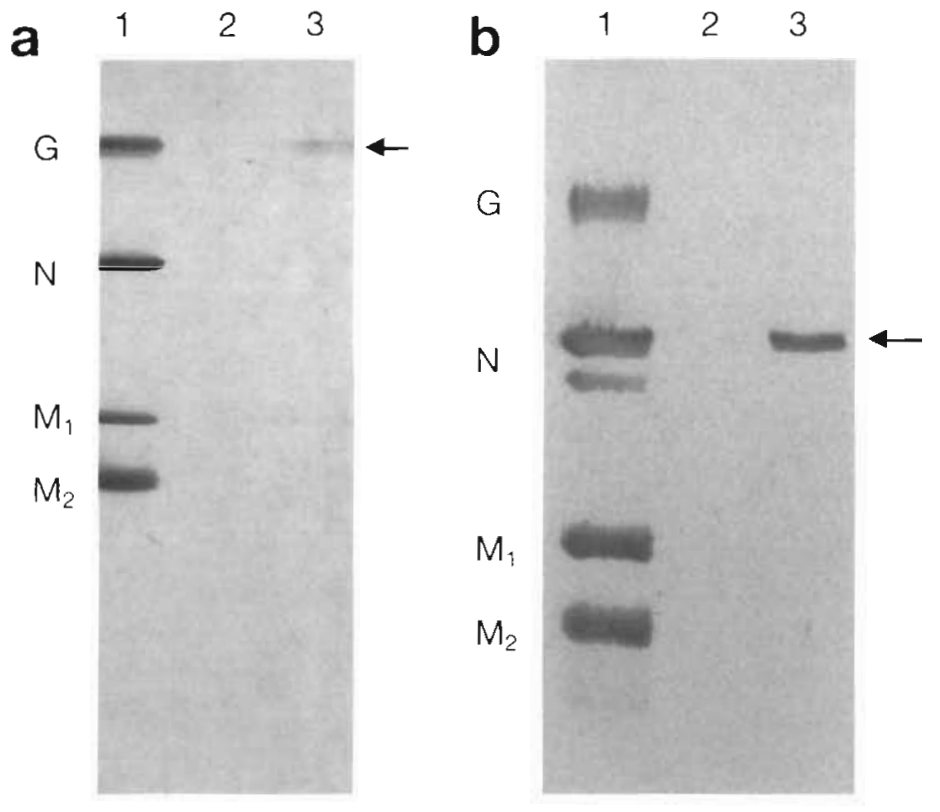

Fig. 4. Western blotting with (a) K59 (rabbit Ig to VHSV) and (b) a pool of MAbs to VHSV, on the structural proteins of: (1) VHSV, (2) IHNV, and (3) carpione virus. Note reactions between K59 and carpione virus $G$ protein (arrow, a) and between the MAb pool and carpione $\mathrm{N}$ protein (arrow, b) shown) and were thus very similar to those of VHSV (Lorenzen et al. 1988). Only the $\mathrm{M}_{2}$ protein of the carpione virus appeared to differ slightly in that it was about $1 \mathrm{kDa}$ smaller than the $\mathrm{M}_{2}$ protein of VHSV

\section{Immunoblotting}

An immunoblot developed using antiserum (K59) to VHSV is shown in Fig $4 \mathrm{a}$. The rabbit anti-VHSV serum reacted with the $G, N, M_{1}$ and $M_{2}$ proteins of VHSV as expected and weakly with the $G$ protein of the carpione virus. The same antiserum also gave a weak reaction with the $\mathrm{M}_{2}$ polypeptide of IHNV. Polyclonal antiserum to IHNV did not react with the carpione virus polypeptides (not shown). Strong staining of the carpione $\mathrm{N}$ protein was observed with MAb IP5B11, which recognizes the VHSV $N$ protein. No staining was observed with MAbs recognizing the $G$, $\mathrm{M}_{1}$ and $\mathrm{M}_{2}$ polypeptides of VHSV (Fig. $4 \mathrm{~b}$ ).

\section{Growth and stability of the virus}

Replication of the carpione virus in different fish cell lines is summarized in Table 1. The highest titres of virus were produced using BF-2 and FHM cells. The temperature optimum for virus replication in EPC cells
Table 1 Replication of the carpione virus in selected fish cell lines.

\begin{tabular}{|lcc|}
\hline $\begin{array}{l}\text { Cell } \\
\text { line }\end{array}$ & $\begin{array}{c}\text { Growth } \\
\text { temp. }\left({ }^{\circ} \mathrm{C}\right)\end{array}$ & $\begin{array}{c}\text { Virus titre } \\
\left(\mathrm{PFU} \mathrm{ml^{-1 }}\right)\end{array}$ \\
\hline $\mathrm{BF}-2$ & 25 & $2 \times 10^{7}$ \\
$\mathrm{CHSE}-214$ & 20 & $3 \times 10^{4}$ \\
EPC & 25 & $8 \times 10^{6}$ \\
FHM & 20 & $2 \times 10^{7}$ \\
OFC & 20 & $3 \times 10^{5}$ \\
PG & 20 & $<$ detection limit \\
RTG-2 & 20 & $4 \times 10^{6}$ \\
SBL & 20 & $2 \times 10^{b}$ \\
& & \\
${ }^{a}$ Titre determined on samples taken after 7 d incubation
\end{tabular}

was $20^{\circ} \mathrm{C}$. The virus was considered to be heat sensitive as it was completely inactivated following a $15 \mathrm{~min}$ exposure to $56^{\circ} \mathrm{C}$ (Table 2), but the virus appeared to be relatively stable at temperatures of $37^{\circ} \mathrm{C}$ and below.

\section{Infection trials}

All groups of carpione fry exposed to carpione virus or to VHSV developed typical signs of rhabdoviral infection, i.e. exophthalmia, dark pigmentation and petechial haemorrhages in muscles and viscera 
Table 2. Titres in EPC cells of the carpione virus following exposure for $15 \mathrm{~min}$ at 5 selected temperatures

\begin{tabular}{|cc|}
\hline Temperature $\left({ }^{\circ} \mathrm{C}\right)$ & Virus titre $\left(\mathrm{PFU} \mathrm{m}{ }^{-1}\right)$ \\
\hline 4 & $1.3 \times 10^{6}$ \\
30 & $1.3 \times 10^{6}$ \\
37 & $1.1 \times 10^{6}$ \\
42 & $4.1 \times 10^{5}$ \\
56 & $<$ detection limit \\
\hline
\end{tabular}

(Fig. 5). High mortality occurred among groups of infected carpione beginning at Day 5 (carpione virus) and Day 7 (VHSV) post-infection. The experiment was stopped after $18 \mathrm{~d}$. Most of the fish from this experiment, with the exception of a few taken for histological examination and for IF, were submitted to virological examination using EPC cells. Unfortunately, mortalities were also observed in the carpione control groups (Table 3), but virus was isolated only from experimentally infected fish. The cause of the mortality in the control groups was not determined but it is suspected that problems with nutrition and management were involved. In bath experiments, rainbow trout fry were not susceptible to carpione virus at passage level 8 , nor to cell culture passage 1 of virus reisolated after passage in fish (Table 3). In contrast, i.p. injection of carpione virus into rainbow trout fry at a concentration of $10^{7}$ TCID $_{50}$ per fish induced a $30 \%$ mortality while injection of $10^{5}$ TCID $_{50}$ per fish produced only a $12 \%$ mortality (results not shown). Specimens of symptomatic fish from carpione virus challenge experiments that were processed for indirect IF using antiserum to carpione virus were positive for carpione virus antigen, whereas control fish and fish infected with VHSV were negative.

\section{DISCUSSION}

The rhabdovirus isolated from carpione fry in Italy appears to be a member of the Lyssavirus genus of the Rhabdoviridae. The estimated molecular weights of the structural polypeptides of the virus were very similar to those reported for VHSV.

The carpione virus was antigenically related to VHSV as shown by IF and immunoblotting. MAbs to both the $N$ and $G$ proteins of VHSV reacted with the carpione virus in IF, whereas only the MAb to the $\mathrm{N}$ protein reacted positively in immunoblotting. Together, the findings clearly show that the carpione and VHS viruses share antigenic determinants on the $N$ and $G$ proteins. The moderate, weak, or negative reaction observed with 3 rabbit polyclonal antisera to VHSV was somewhat surprising, considering the reactions observed with the MAbs, because these sera reacted strongly with the 3 isolates of VHSV in both IF and immunoblotting. It has previously been shown that both polyclonal antibodies and pools of monoclonal antibodies made against VHSV reference strain F1 react strongly in IF and immunoblotting with the polypeptides of virus isolates representing all the currently known serological groups of VHSV (Olesen et al. 1993, Olesen \& Jørgensen unpubl. data). One possi-

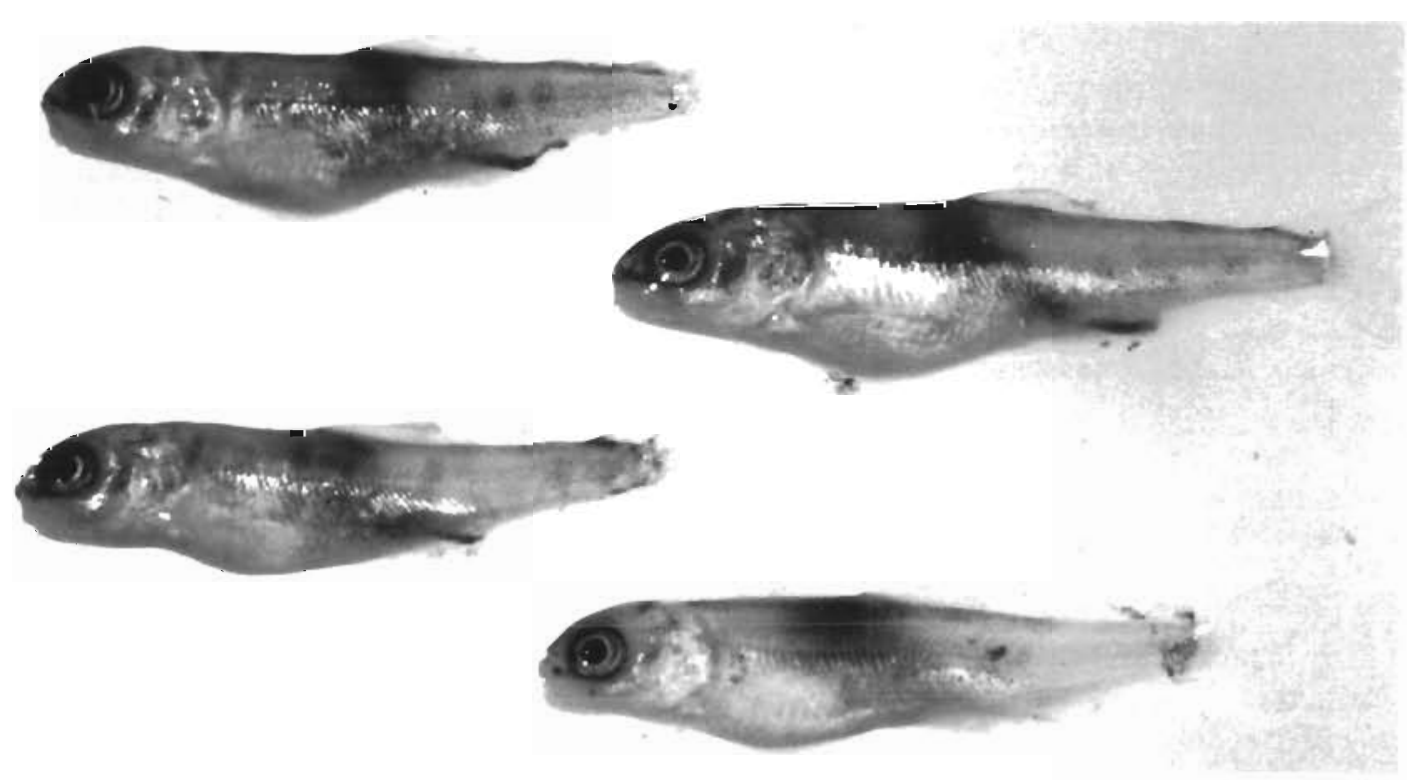

Fig. 5. Salmo trutta carpio. Darkening of the body surface and presence of haemorrhagic lesions in carpione fry experimentally infected with the carpione virus 
Table 3. Results of bath infection of rambow trout Oncorhynchus mykiss and carpione Salmo trutta carpio fry with VHSV and carpione virus

\begin{tabular}{|lcclcc|}
\hline Species & $\mathrm{n}$ & $\begin{array}{c}\text { Size } \\
(\mathrm{g})\end{array}$ & Virus & $\begin{array}{c}\text { Challenge } \\
\left(\mathrm{TCID}_{50} \mathrm{ml}^{-1}\right)\end{array}$ & $\begin{array}{c}\text { Morta- } \\
\text { lity } \%\end{array}$ \\
\hline Carpione & 50 & 0.1 & Carpione 583 & $2 \times 10^{\circ}(\mathrm{a})$ & 86 \\
& 50 & 0.1 & Carpione 583 & $2 \times 10^{\circ}(\mathrm{a})$ & 92 \\
& 50 & 0.1 & Carpione 583 & $2 \times 10^{\circ}(\mathrm{a})$ & 74 \\
& 50 & 0.1 & VHSV (Saone) & $4 \times 10^{3}(\mathrm{a})$ & 66 \\
& 50 & 0.1 & VHSV (Saone) & $4 \times 10^{3}(\mathrm{a})$ & 72 \\
& 50 & 0.1 & Control & $-(\mathrm{a})$ & 52 \\
& 50 & 0.1 & Control & $-(\mathrm{a})$ & 26 \\
Rainbow trout & 50 & 2.0 & Carpione 583 & $1 \times 10^{5}(\mathrm{a})$ & 0 \\
& 50 & 2.0 & Carpione 583 & $1 \times 10^{5}(\mathrm{a})$ & 0 \\
& 50 & 2.0 & VHSV (Saone) & $1 \times 10^{5}(\mathrm{a})$ & 100 \\
& 50 & 1.25 & Carpione 583 & $1 \times 10^{5}(\mathrm{~b})$ & 0 \\
& 50 & 1.25 & Carpione 583 & $1 \times 10^{5}(\mathrm{~b})$ & 0 \\
& 50 & 1.25 & VHSV (3592B) & $1 \times 10^{5} \mathrm{i}(\mathrm{b})$ & 98 \\
& 50 & 1.25 & VHSV (3592B) & $1 \times 10^{5}(\mathrm{~b})$ & 98 \\
& 50 & 1.25 & Control & $-(\mathrm{b})$ & 0 \\
& 50 & 1.25 & Control & $-(\mathrm{b})$ & 0 \\
& & & & \\
\hline $\mathrm{a}=10^{\circ} \mathrm{C}, \mathrm{b}=15^{\circ} \mathrm{C}$ & & & &
\end{tabular}

ble reason for the relatively weak staining of carpione antigens by rabbit antisera against VHSV is a lower average affinity of the polyclonal antibodies than of the MAbs. The difference in affinity might have been particularly obvious when the antibodies were reacted with antigens which were related but not completely identical with the homologous ones.

In the immunoblotting, the occurrence of 2 stained protein bands at $41 \mathrm{kDa}$ (the $\mathrm{N}$ protein) with the MAbs (Fig. 4b) most likely was due to proteolysis of the $\mathrm{N}$ protein (Lorenzen 1992). The slight reaction observed between rabbit anti-VHSV and the $M_{2}$ protein of IHNV may indicate that IHNV and VHSV possess related epitopes on the $M_{2}$ proteins, as has also been suggested by studies using certain MAbs (Dr J.-P. Enzmann, Tübingen, Germany, pers. comm.; author's unpubl. results).

Despite the fact that VHSV and the carpione virus contained an unknown number of related antigenic sites, it was concluded that the carpione virus was clearly distinct from VHSV and the other fish rhabdoviruses tested. The relatively weak reaction with polyclonal antibodies to VHSV suggested that the serological relationship between the 2 viruses is somewhat distant. In another study (Jørgensen et al. 1993), the carpione virus was found to be serologically related only with VHSV among the 12 currently available fish rhabdoviruses, including the recent isolates from European lake trout in Finland (Koski et al. 1992) and pike in Denmark (Jørgensen et al. 1993).

On the basis of the compiled serological data we conclude that the virus from carpione brown trout is a distinct, previously undescribed fish rhabdovirus. As a preliminary name we propose 'carpione rhabdovirus'.

Based upon the results of the infection trials, it seemed likely that the carpione virus was responsible for the losses recorded in the carpione fry. Unfortunately, only very small carpione fry $(0.1 \mathrm{~g})$ were available for experimental infection, and thus it cannot be excluded that the pathogenicity of the virus might be restricted to fry of that size. The virus did not infect rainbow trout fry by bath infection and only injection of a large number of infective particles induced mortality in fish of this species. The lack of pathogenicity of the virus for rainbow trout apparently was not due to cell culture adaptation, since carpione virus isolated from moribund experimental rainbow trout and passed only once in cell cultures was also nonpathogenic.

\section{LITERATURE CITED}

Ahne W (1979) Fish cell cultures: a fibroblastic line (PG) from ovaries of juvenile pike (Esox lucius). In Vitro 15: $839-840$

Castric J (1984) Obtention et etude de quelques caractéristiques d'une lignee cellulaire du bar, Morone labrax (Linné). Mémoire, Faculté des sciences de Brest, Université de Bretagne Occidentale

Fijan N, Sulimanovic D, Bearzotti M, Muzinic D, Zwillenberg LO, Chilmonczyk S, Vautherot JF, de Kinkelin P (1983) Some properties of the epithelioma papulosum cyprini (EPC) cell line from carp Cyprinus carpio. Annls Virol (Inst Pasteur) 134(E):207-220

Gravell M, Malsberger RG (1965) A permanent cell line from fathead minnow (Pimephales promelas). Ann NY Acad Sci 126:555-565

Jensen M (1965) Research on the virus of Egtved disease. Ann NY Acad Sci 126:422-426

Jorgensen PEV, Olesen NJ, Ahne W, Wahli T, Meier W (1993) Isolation of a previously undescribed rhabdovirus from pike Esox lucius. Dis aquat Org 16:171-179

Koski P, Hill BJ, Way K, Neuvonen E, Rintamäki P (1992) A rhabdovirus isolated from brown trout (Salmo trutta lacustris (L)) with lesions in parenchymatous organs. Bull Eur Ass Fish Pathol 12:177-180

Kyhse-Andersen J (1984\} A simple horizontal apparatus without buffer tank for electrophoretic transfer of proteins from polyacrylamide to nitrocellulose. $\mathrm{J}$ biochem biophys Meth 10:203-209

Laemmli UK (1970) Cleavage of structural proteins during assembly of the head of bacteriophage T4. Nature 227 680-685

Lannan CN, Winton JR, Fryer JL (1984) Fish cell lines: establishment and characterization of nine cell lines from salmonids. In Vitro 20:671-676

Lorenzen N (1992) Affinity purification of the structural proteins of a fish Rhabdovirus by the use of monoclonal antibodies. J viral Meth 38:297-303 
Lorenzen N, Olesen NJ, Jørgennsen PEV (1988) Production and characterization of monoclonal antibodies to four Egtved virus structural proteins. Dis aquat Org 4:35-42

Melotto S, Oppi E (1987) Status of the present knowledge of 'Carpione', a Gorda endemism. In: Proceedings of AlIAD, 2nd Conference, Torino, p 239-249

Morrissey JH (1981) Silver stain for proteins in polyacrylamide gels: a modified procedure with enhanced uniform sensitivity. Analyt Biochem 117:307-310

Olesen NJ, Lorenzen N, Jørgensen PEV (1991) Detection of rainbow trout antibody to Egtved virus by enzyme-linked immunosorbent assay (ELISA), immunofluorescence (IF), and plaque neutralization tests ( $50 \%$ PNT). Dis aquat Org $10: 31-38$

Responsible Subject Editor: F. M. Hetrick, College Park, Maryland, USA
Olesen NJ, Lorenzen N, Jørgensen PEV (1993) Serological differences among isolates of viral haemorrhagic septicaemia virus detected by neutralizing monoclonal and polyclonal antibodies. Dis aquat Org 16:163-170

Reed LJ, Muench H (1938) A simple method of estımating fifty percent end points. Am J Hygiene 27:493-497

Wagner RR, Prevec L, Summers DF, Sokol F, McLeod R (1972) Classification of rhabdovirus proteins: a proposal. J Virol 10:1228-1230

Wolf K, Quimby MC (1962) Established eurythermic line of fish cells in vitro. Science 135:1965-1966

Wolf K, Quimby MC (1966) Lymphocystis virus: isolation and propagation in centrarchid fish cell lines. Science 151: $1004-1005$

Manuscript first received: February 9, 1994

Revised version accepted: October 7, 1994 